\title{
Responses of Water Use Efficiency to Drought in Southwest China
}

\author{
Jingxue Zhao ${ }^{1}$, Tongren $\mathrm{Xu}^{1}{ }^{1}{ }^{*}$, Jingfeng Xiao ${ }^{2} \mathbb{D}$, Shaomin Liu ${ }^{1}$, Kebiao Mao ${ }^{3} \mathbb{D}$, Lisheng Song ${ }^{4}$, \\ Yunjun Yao ${ }^{5}$, Xinlei He ${ }^{1}$ and Huaize Feng ${ }^{1}$ \\ 1 State Key Laboratory of Earth Surface Processes and Resource Ecology, Faculty of Geographical Science, \\ Beijing Normal University, Beijing 100875, China; 201821051096@mail.bnu.edu.cn (J.Z.); \\ smliu@bnu.edu.cn (S.L.); hxlbsd@mail.bnu.edu.cn (X.H.); fenghuaize@mail.bnu.edu.cn (H.F.) \\ 2 Earth Systems Research Center, Institute for the Study of Earth, Oceans, and Space, \\ University of New Hampshire, Durham, NH 03824, USA; j.xiao@unh.edu \\ 3 Institute of Agricultural Resources and Regional Planning, Chinese Academy of Agricultural Sciences, \\ Beijing 100081, China; maokebiao@caas.cn \\ 4 School of Geographical Sciences, Southwest University, Chongqing 400715, China; songls@swu.edu.cn \\ 5 State Key Laboratory of Remote Sensing Science, Faculty of Geographical Science, Beijing Normal University, \\ Beijing 100875, China; yaoyunjun@bnu.edu.cn \\ * Correspondence: xutr@bnu.edu.cn; Tel.: +86-10-5880-7455
}

Received: 7 November 2019; Accepted: 3 January 2020; Published: 6 January 2020

check for updates

\begin{abstract}
Water use efficiency (WUE) measures the tradeoff between carbon uptake and water consumption in terrestrial ecosystems. It remains unclear how the responses of WUE to drought vary with drought severity. We assessed the spatio-temporal variations of ecosystem WUE and its responses to drought for terrestrial ecosystems in Southwest China over the period 2000-2017. The annual WUE values varied with vegetation type in the region: Forests $\left(3.25 \mathrm{gC} \mathrm{kg}^{-1} \mathrm{H}_{2} \mathrm{O}\right)>$ shrublands $\left(2.00 \mathrm{gC} \mathrm{kg}^{-1} \mathrm{H}_{2} \mathrm{O}\right)>$ croplands $\left(1.76 \mathrm{gC} \mathrm{kg}^{-1} \mathrm{H}_{2} \mathrm{O}\right)>$ grasslands $\left(1.04 \mathrm{gC} \mathrm{kg}^{-1} \mathrm{H}_{2} \mathrm{O}\right)$. During the period 2000-2017, frequent droughts occurred in Southwest China, and overall, drought had an enhancement effect on WUE. However, the effects of drought on WUE varied with vegetation type and drought severity. Croplands were the most sensitive to drought, and slight water deficiency led to the decline of cropland WUE. Over grasslands, mild drought increased its WUE while moderate and severe drought reduced its WUE. For forests and shrublands, mild and moderate drought increased their WUE, and only severe drought reduce their WUE, indicating that these ecosystems had stronger resistance to drought. Assessing the patterns and trends of ecosystem WUE and its responses to drought are essential for understanding plant water use strategy and informing ecosystem water management.
\end{abstract}

Keywords: water use efficiency; drought; gross primary production; evapotranspiration; remote sensing; resistance; resilience; photosynthesis; water stress; MODIS

\section{Introduction}

Water use efficiency (WUE) is the ratio of carbon gain (or gross primary production, GPP) to water consumption (or evapotranspiration, ET). As an important indicator of the coupling between the carbon and water cycles, WUE closely links biological processes (e.g., photosynthesis, transpiration) with physical processes (e.g., evaporation) [1,2]. WUE measures the tradeoff between carbon uptake and water consumption of terrestrial ecosystems, and is an important indicator for understanding the responses of terrestrial ecosystems to climate change [3].

Ecosystem WUE is influenced by many biological and abiotic factors. For example, a previous study based on eddy covariance data [4] suggested that forest WUE increased because of the elevated 
atmospheric carbon dioxide concentrations while this hypothesis was challenged by a recent study [5] based on 30-year tree ring records of carbon and oxygen isotope measurements, basal area increment, and eddy covariance measurements. This new study [5] disentangled the relative effects of photosynthesis and stomatal conductance on rising forest WUE, and found that rising forest WUE was mainly due to enhanced photosynthesis and partly due to reductions in stomatal conductance. WUE also decreased with the increase of elevation and solar radiation and increased with temperature, precipitation, and leaf area index (LAI) [6]. Moreover, WUE varies with vegetation type. For example, a previous study showed that the WUE of deciduous broad forests was higher than that of evergreen needle forests; stomatal conductance mainly controlled the increase of WUE in deciduous broad forests while the increase of GPP led to the increase of WUE in evergreen needle forests [7]. In addition, WUE is affected by drought, and the responses of WUE to water stress vary over space. For example, Liu et al. [8] found that drought generally reduced WUE in central China but increased WUE in central Inner Mongolia and Northeast China. Guo et al. [9] found that the WUE increased in Northeast China, Northeast Inner Mongolia, and some regions with abundant forests in South China, and declined in Northwest and Central China during drought periods.

Drought has become one of the main obstacles to the health of ecosystems by reducing soil water availability and plant carbon uptake $[10,11]$. With the acceleration of global climate change, the frequency and intensity of drought have been increasing regionally and globally [12-15]. Drought can limit plant growth and lead to forests fires, crop yield reduction, land degradation, and biological invasion $[3,16,17]$. Meanwhile, drought can reduce plant transpiration and disturb the global water balance [18]. Up to now, the impact of drought on ecosystem WUE has received growing attention in scientific research [19-25]. A previous study found that annual WUE decreased in moderate and extreme drought but slightly increased in severe drought [8]. In addition, Yang et al. [10] found that drought increased WUE in arid areas and decreased WUE in semi-arid and sub-humid areas, and different ecosystems had different sensitivity to the changes of hydrological and climatic conditions. However, another study showed that the global WUE had a negative response to drought in arid areas while it had both positive and negative responses in humid areas [26]. Li et al. [27] found that the 2009-2010 drought in Southwest China inhibited the growth of vegetation in Yunnan, northern Guangxi, Guizhou, and eastern Sichuan and led to the decline of primary productivity and carbon uptake. Although the effects of drought on WUE have been well studied [28,29], it remains unclear how the responses of WUE vary with drought severity.

In this study, we examined the responses of WUE to drought in Southwest China from 2000 to 2017 using the scPDSI (Self-calibrating Palmer Drought Severity Index) [30] and MODIS (Moderate-resolution Imaging Spectroradiometer) GPP and ET data. Southwest China has experienced frequent droughts and provides a test bed for studying the responses of WUE to drought. We examined the spatial and temporal variations of drought, and analyzed how the responses of WUE to drought varied with vegetation type and drought severity. Our results can help us better understand the responses and adaptability of ecosystems to drought.

\section{Materials and Methods}

\subsection{Study Area}

Southwest China $\left(97.5-110.2^{\circ} \mathrm{E}, 21.1-34.3^{\circ} \mathrm{N}\right)$ is mainly composed of Sichuan, Chongqing, Yunnan, and Guizhou provinces, and the total land area is $1,138,700 \mathrm{~km}^{2}$. The natural divisions mainly consist of the Sichuan Basin, Western Sichuan Plateau, Yunnan-Guizhou Plateau, and the west of Liang-Guang Hills. The main vegetation types of Southwest China are forests, shrublands, grasslands, and croplands (mainly including rice, corn, rape, flue-cured tobacco), which account for 18.87\%, 16.83\%, 22.25\%, and $25.16 \%$ of the land area, respectively. Croplands are mainly distributed in the Sichuan Basin and Zhong-Shan hilly area of Guizhou province; the high-elevation areas, such as the western Sichuan 
Plateau, are mainly covered by grasslands; most of southern Sichuan and Yunnan are dominated by forests (Figure 1a).

Southwest China is characterized by a large elevation gradient: The elevation of the Sichuan Basin and its surrounding areas as well as eastern Guizhou is less than $1000 \mathrm{~m}$; the elevation of southern Sichuan and Northwest Yunnan is between 1000 and 2000 m; and the elevation of the western Sichuan Plateau is above $3500 \mathrm{~m}$ (Figure $1 \mathrm{~b}$ ). Air temperature and precipitation exhibit large variations across the region. The annual mean temperature is higher than $10^{\circ} \mathrm{C}$ in the eastern region and is lower than $0{ }^{\circ} \mathrm{C}$ in the western Sichuan Plateau (Figure 1c). The annual precipitation is relatively high $(>1000 \mathrm{~mm})$ in the eastern and southern regions and much lower in the central and northern regions (Figure 1d).

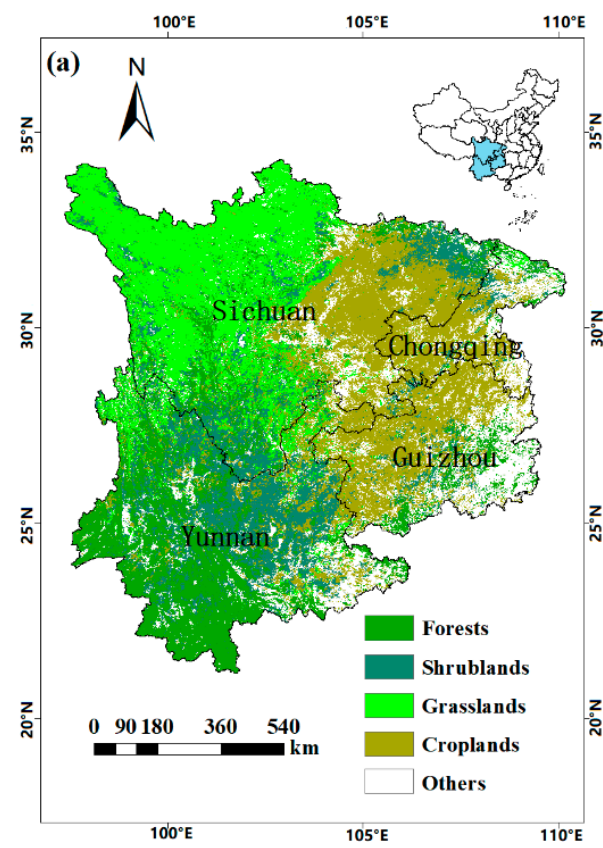

(b)
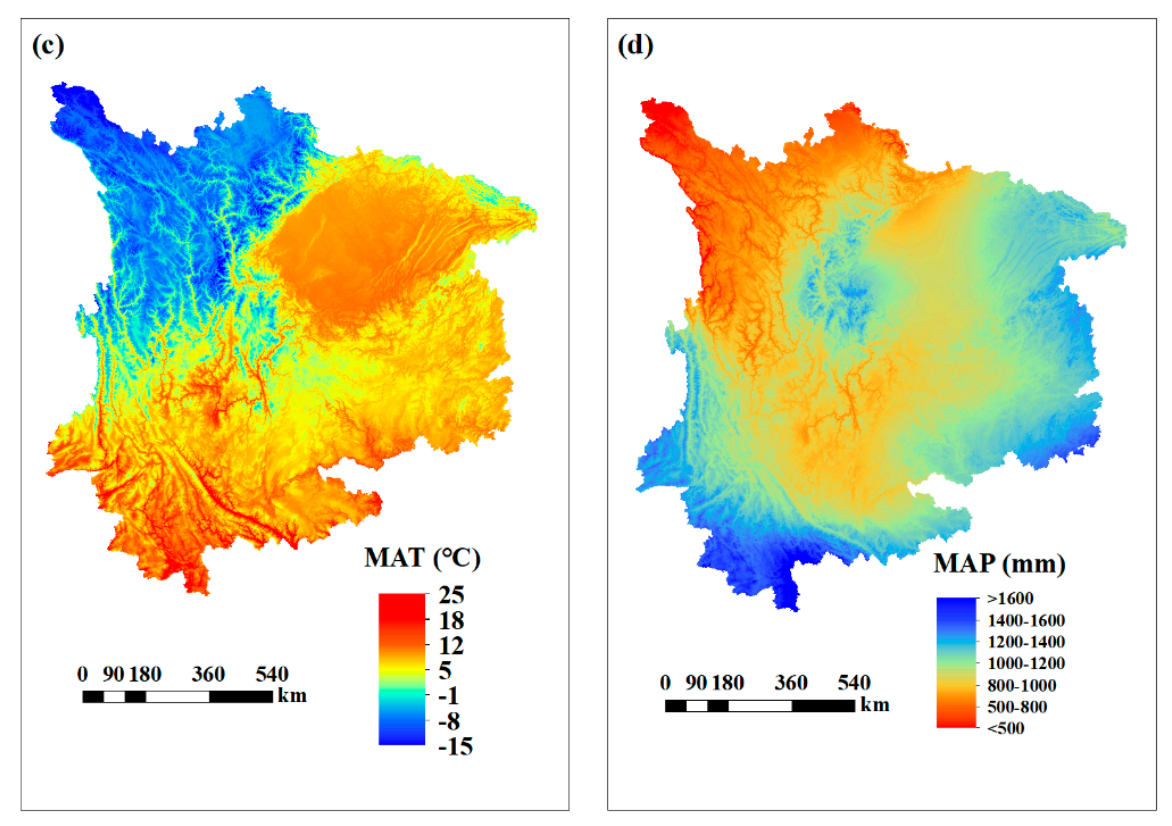

Figure 1. The land cover, elevation, and climate of Southwest China: (a) land cover types; (b) elevation; (c) mean annual temperature (MAT); (d) mean annual precipitation (MAP). 


\subsection{Datasets}

The data used in this study mainly include climate, remote sensing (GPP, ET, and land cover), drought index, and digital elevation model (DEM). The specific data sets and detailed information on the data are provided in Table 1.

Table 1. Data information.

\begin{tabular}{cccccc}
\hline Data & Name & $\begin{array}{c}\text { Spatial } \\
\text { Resolution }\end{array}$ & $\begin{array}{c}\text { Temporal } \\
\text { Resolution }\end{array}$ & Period & References \\
\hline Climate Data & $\begin{array}{c}\text { Temperature } \\
\text { Precipitation }\end{array}$ & $\begin{array}{c}1 \mathrm{~km} \\
1 \mathrm{~km}\end{array}$ & $\begin{array}{c}\text { Monthly } \\
\text { Monthly }\end{array}$ & $\begin{array}{c}2000-2017 \\
2000-2017\end{array}$ & $\begin{array}{c}\text { China Meteorological Data } \\
\text { Service Center }\end{array}$ \\
\hline $\begin{array}{c}\text { Geographic } \\
\text { data }\end{array}$ & DEM & $1 \mathrm{~km}$ & - & 2000 & $\begin{array}{c}\text { SRTM 90m DEM Digital Elevation } \\
\text { Database }\end{array}$ \\
\cline { 2 - 6 } & Land Cover & $1 \mathrm{~km}$ & - & 2010 & $\begin{array}{c}\text { Data center of resources and } \\
\text { environmental sciences, Chinese } \\
\text { academy of sciences }\end{array}$ \\
\hline $\begin{array}{c}\text { Remote sensing } \\
\text { products }\end{array}$ & GPP & $1 \mathrm{~km}$ & Monthly & $2000-2017$ & $\begin{array}{c}\text { MOD17A2 } \\
\text { MOD16A2 }\end{array}$ \\
\hline Drought index & scPDSI & $0.5^{\circ}$ & Monthly & $2000-2017$ & Climatic Research Unit \\
\hline
\end{tabular}

The monthly temperature and precipitation datasets for the period 2000-2017 were obtained from the China Meteorological Data Service Center (http://data.cma.cn/). For each grid cell across Southwest China, the monthly station records were aggregated annually to calculate annual temperature and annual precipitation for each year over the study period. We also calculated the mean annual temperature (MAT) and mean annual precipitation (MAP).

The land cover data with a spatial resolution of $1 \mathrm{~km}$ obtained from the Data Center of Resources and Environmental Sciences (http://www.resdc.cn/Default.aspx) was used to identify the vegetation type of each grid cell. The four broad vegetation types examined in this study are forests, shrublands, grasslands, and croplands.

The monthly MODIS GPP [31,32] and ET [33,34] data (with a 1-km resolution) during the period 2000-2017 were both obtained from University of Montana (http://www.ntsg.umt.edu). The reliability and accuracy of the GPP product (MOD17A2) have been evaluated by many previous studies [35-39], and it has been compared with ground-based data from various terrestrial ecosystems [32,35]. The ET product (MOD16A2) is based on meteorological reanalysis data and vegetation attributes [34,40], and has been evaluated with flux tower data from the United States [40,41], Asia [42], and other regions.

The global monthly Self-calibrating Palmer Drought Severity Index (scPDSI) with a $0.5^{\circ}$-spatial resolution was obtained from the Climatic Research Unit (https://crudata.uea.ac.uk/cru/data/drought/). This drought index was used to analyze the drought conditions and the influences of drought on WUE during the period from 2000 to 2017. The scPDSI metric [30] was proposed based on the Palmer drought severity index (PDSI) [43], and the scPDSI is more comparable across different climate regimes than the traditional Palmer drought severity index (PSDI). The scPDSI was calculated from monthly precipitation and air temperature data at each location. The values of scPDSI range from -5.0 to 5.0, which indicates drought to humid conditions. Following Wang et al. [44], the wet or dry conditions are divided into three categories: Drought (scPDSI $\leq-1)$, normal $(-1<\operatorname{scPDSI}<1)$, and humid ( $1 \leq \mathrm{scPDSI}$ ), while the drought category can be further divided into slight drought, moderate drought, severe drought, and extreme drought (Table 2). 
Table 2. The wet or dry conditions based on scPDSI.

\begin{tabular}{cc}
\hline scPDSI & Wet or Dry Conditions \\
\hline$\geq 4$ & Extreme humid \\
$3-4$ & Severe humid \\
$2-3$ & Moderate humid \\
$1-2$ & Slight humid \\
$-1-1$ & Normal \\
$-2--1$ & Slight drought \\
$-3--2$ & Moderate drought \\
$-4--3$ & Severe drought \\
$\leq-4$ & Extreme drought \\
\hline
\end{tabular}

\subsection{Analysis}

For each grid cell in the study region, we calculated annual GPP and ET from the monthly GPP and ET, respectively, for each year over the period 2000-2017. We then calculated annual WUE for each grid cell over the 18-year period from annual GPP and ET. The ecosystem WUE $\left(\mathrm{gC} \mathrm{kg}^{-1} \mathrm{H}_{2} \mathrm{O}\right)$ of an ecosystem can be expressed as follows [45]:

$$
\text { WUE }=\text { GPP/ET }
$$

where WUE, GPP, and ET are the annual WUE, GPP, and ET, respectively.

In this study, the proportion of the pixels affected by drought in Southwest China was used to measure the spatial extent of drought across the region. To assess the temporal variations in WUE and scPDSI, the linear trends of per-pixel annual WUE and scPDSI over the period 2000-2017 were calculated by using the ordinary least square regression (OLSR) method. For each grid cell, the trend was considered to be statistically significant if the $p$ value was less than 0.05 . The grid cells with missing values were excluded in our analysis.

In order to compare and analyze the effects of drought on WUE, we calculated the difference of annual WUE ( $\triangle$ WUE) between the drought year and the normal year in the same region. If $\triangle W U E$ values are greater than 0 , WUE exhibits positive anomalies and drought likely increases WUE; if $\triangle W U E$ values are less than 0 , WUE shows negative anomalies and drought likely decreases WUE. The nonlinear correlation analysis was used to study the responses of annual WUE to drought.

The trend of scPDSI from 2000 to 2017 was calculated with the Mann-Kendall (M-K) method, following $[46,47]$. The M-K test does not require that samples follow a certain distribution, and it is also insensitive to outliers. This method is suitable for data with a non-normal distribution (e.g., hydrological and meteorological data). Many previous studies used the M-K method to analyze the trend in time series of precipitation, temperature, runoff, and water quality $[48,49]$.

\section{Results}

\subsection{Spatial and Temporal Variations of Drought in Southwest China}

The total land area affected by drought in Southwest China showed large interannual variations from 2000 to 2017 (Figure 2a). Overall, the drought area accounted for nearly half of the total land area in 2006. During the period 2010-2013, the drought area exceeded 55\% of the entire region for four consecutive years. After 2013, the drought area substantially decreased due to the alleviation of drought. The drought area for the four broad vegetation types showed generally similar interannual variations (Figure 2b). The severe drought and extreme drought occurred in the region in 2006 and 2010 were also reported in the literature [8,27]. We used the proportion of the drought area in Southwest China to measure the spatial extent of drought, and selected 2006 and 2010 as two drought years for further analysis. 

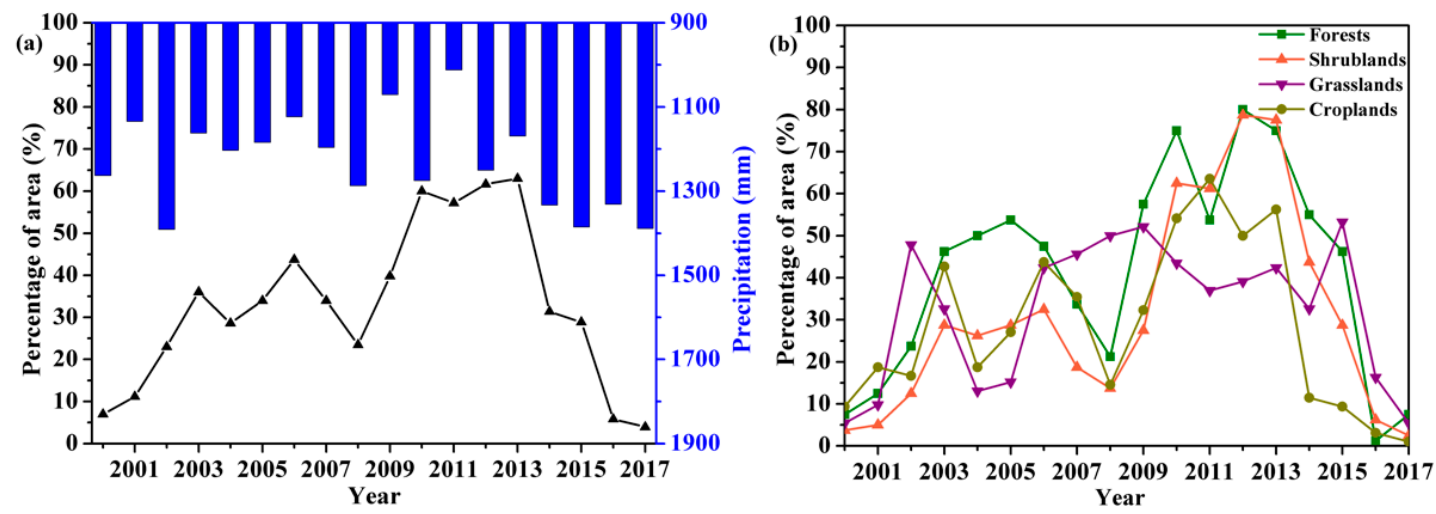

Figure 2. The interannual variations of the drought area (scPDSI $<-1$ ) and precipitation in Southwest China over the period 2000-2017: (a) the drought area and annual precipitation for all vegetated grid cells; (b) the drought area for different vegetation types.

The spatial distribution, the frequency of drought (scPDSI $<-1$ ), and the trend of scPDSI from 2000 to 2017 are shown in Figure 3. On average, most parts of Southwest China were characterized by "normal" or slight drought categories (Figure 3a). The frequency of drought was relatively high in Southwestern Yunnan and central Sichuan (Figure 3b). During the 18-year period, drought occurred more than 10 times for many areas in Southwest China. The Sichuan Basin and the junction of Sichuan and Yunnan were relatively humid with low drought frequency ( $0-5$ times). Figure $3 c$ showed the scPDSI trend from 2000 to 2017 calculated with the M-K method. The scPDSI in the Sichuan Basin showed a significant increasing trend from 2000 to 2017, indicating that this region exhibited a wetting trend. By contrast, the scPDSI showed a significant decreasing trend in Northwest Yunnan and Southwest Sichuan, indicating a drying trend in this region.
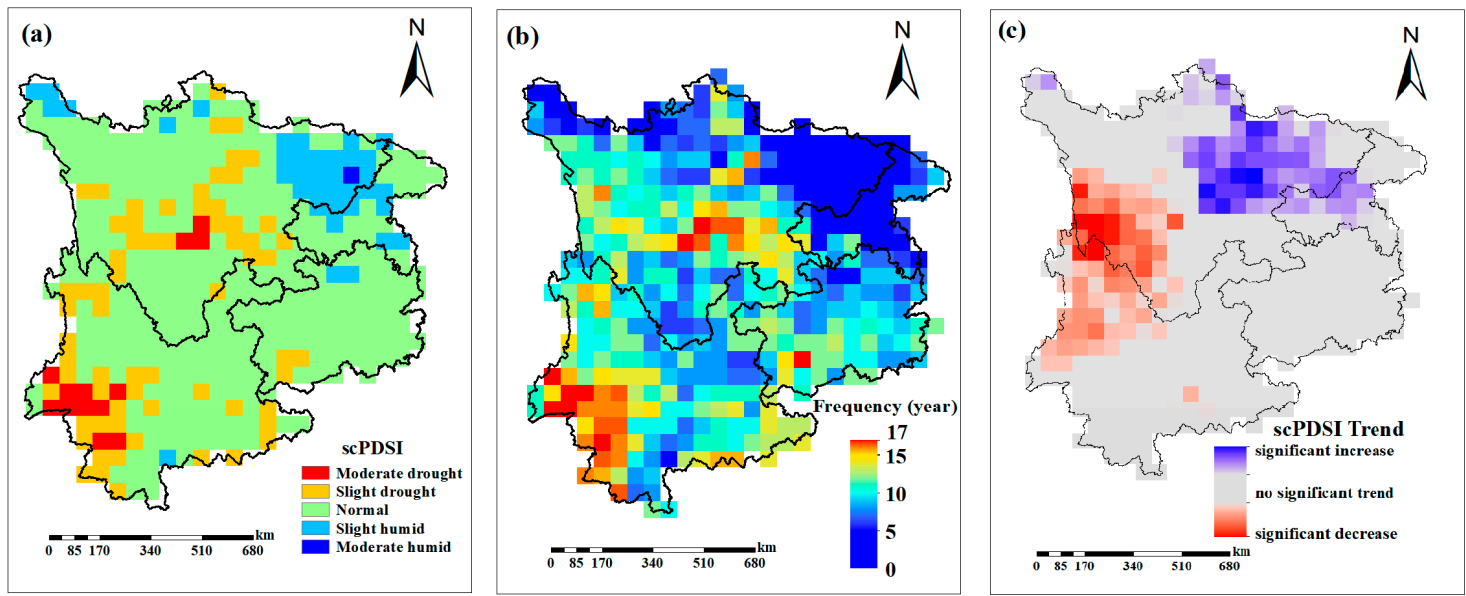

Figure 3. The spatial distribution, frequency, and trend of drought as measured by scPDSI in Southwest China over the period 2000-2017: (a) the spatial distribution of the long-term mean scPDSI; (b) the frequency map of drought occurrence; (c) the scPDSI trend.

\subsection{Spatial and Temporal Variations of WUE in Southwest China}

The annual WUE of the terrestrial ecosystems in Southwest China fluctuated greatly from 2000 to 2017 with a multi-year mean value of $1.70 \mathrm{gC} \mathrm{kg}^{-1} \mathrm{H}_{2} \mathrm{O}$ (Figure 4a). Over the entire study period 2000-2017, the annual WUE generally showed a decreasing trend that was statistically insignificant except for croplands (Figure 4a-e). With the start (2000) and end (2017) years with particularly low WUE values excluded, the trends of WUE were statistically significant for all vegetated grid cells (Figure 4a) and croplands (Figure 4e). Moreover, WUE also exhibited a declining trend for each of the 
four main vegetation types (Figure $4 \mathrm{~b}-\mathrm{e}$ ). In addition, the mean annual WUE differed among vegetation types: Forests had the largest WUE (3.25 gC kg-1 $\left.\mathrm{H}_{2} \mathrm{O}\right)$, followed by shrublands $\left(2.00 \mathrm{gC} \mathrm{kg}^{-1} \mathrm{H}_{2} \mathrm{O}\right)$, croplands (1.76 gC kg $\left.{ }^{-1} \mathrm{H}_{2} \mathrm{O}\right)$, and grasslands (1.04 $\mathrm{gC} \mathrm{kg}^{-1} \mathrm{H}_{2} \mathrm{O}$ ) (Figure $\left.4 \mathrm{~b}-\mathrm{e}\right)$.

The annual WUE was relatively high in Yunnan, southern Sichuan, and Southwestern Sichuan Basin and relatively low in the Western Sichuan Plateau and Guizhou (Figure 5a). The WUE trends based on the Mann-Kendall method were divided into three categories: Significant increase (slope $>0$, $p<0.05$ ), no significant trend $(p<0.5)$, and significant decrease (slope $<0, p<0.05)$ [49]. The WUE trends from the Mann-Kendall method are shown in Figure 5b. From 2000 to 2017, most vegetated grid cells in the study region had no significant trends; The annual WUE in the Sichuan Basin and northern Sichuan showed significant decreases while the annual WUE in the Northwest, Northeast, and eastern Yunnan significantly increased. From Figures $3 b$ and $5 b$, it can be found that the areas with significant increases in scPDSI (drought relief or wetting) were generally consistent with those areas with significant decreases in WUE; the areas with significant decreases in scPDSI (drying or drought aggravation) were generally consistent with those areas with significant increases in WUE. Therefore, drought had an enhancement effect on WUE over Southwest China.
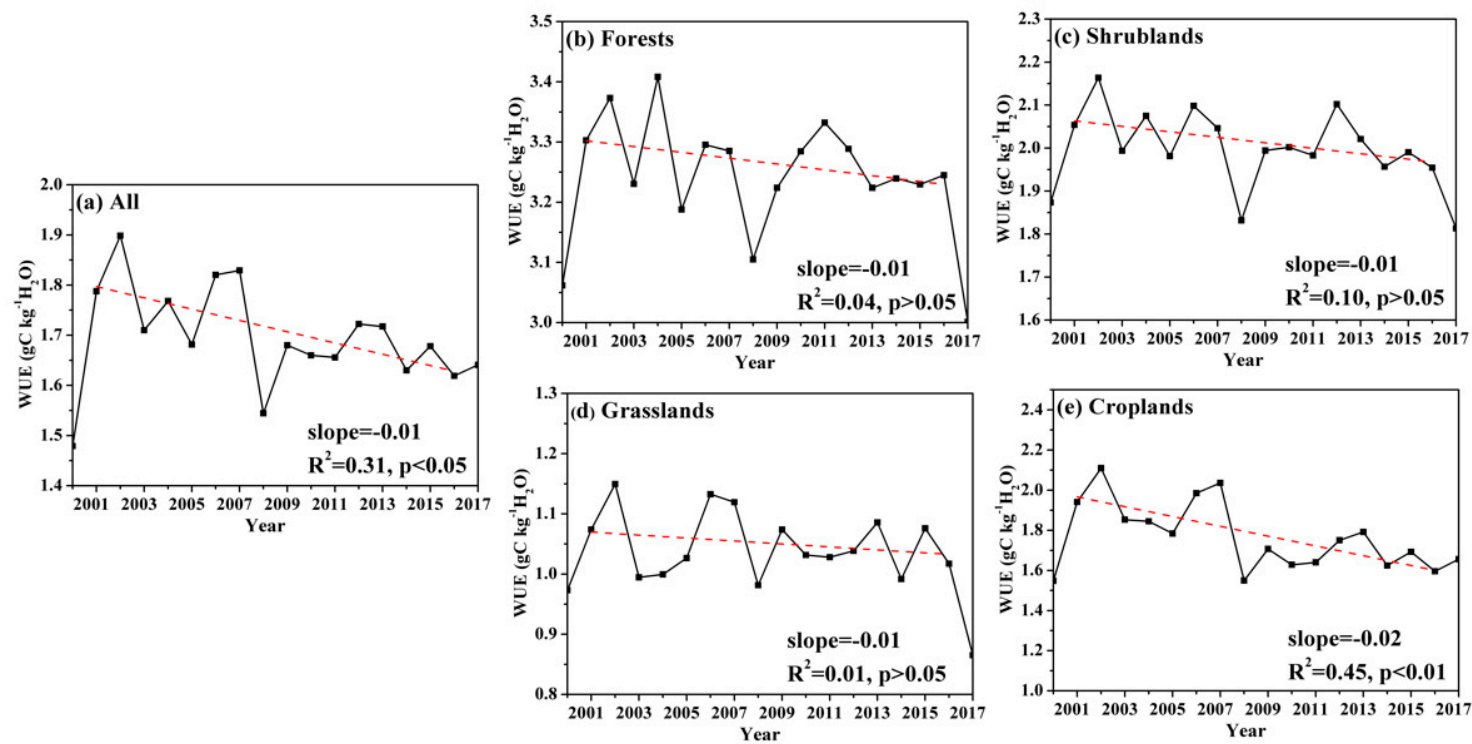

Figure 4. The variations and trends of spatially averaged annual WUE in Southwest China over the period 2000-2017: (a) all vegetated grid cells; (b) forests; (c) shrublands; (d) grasslands; and (e) croplands. The dashed, red lines are the trend lines over the period 2001-2016, and the start (2000) and end (2017) years of the study period (2000-2017) are excluded to remove the effects of the start and the end years. The trend lines over the period 2000-2017 are not statistically significant except for croplands and are not plotted. 
(a)

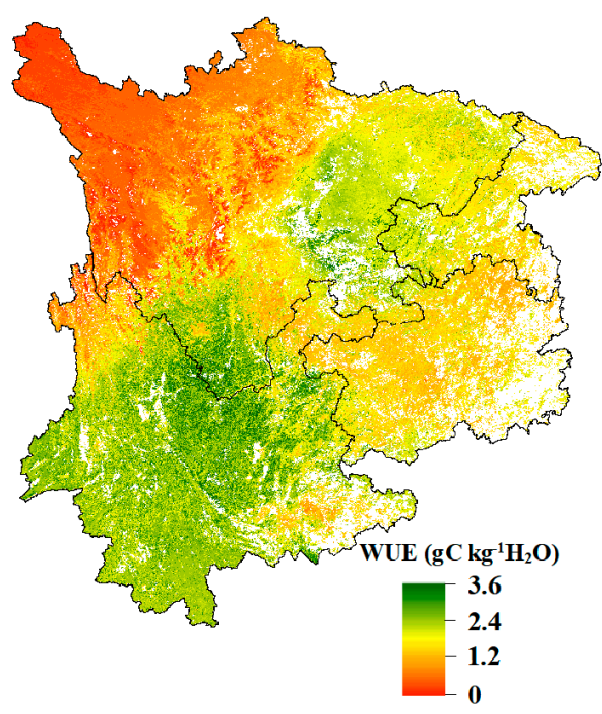

(b)

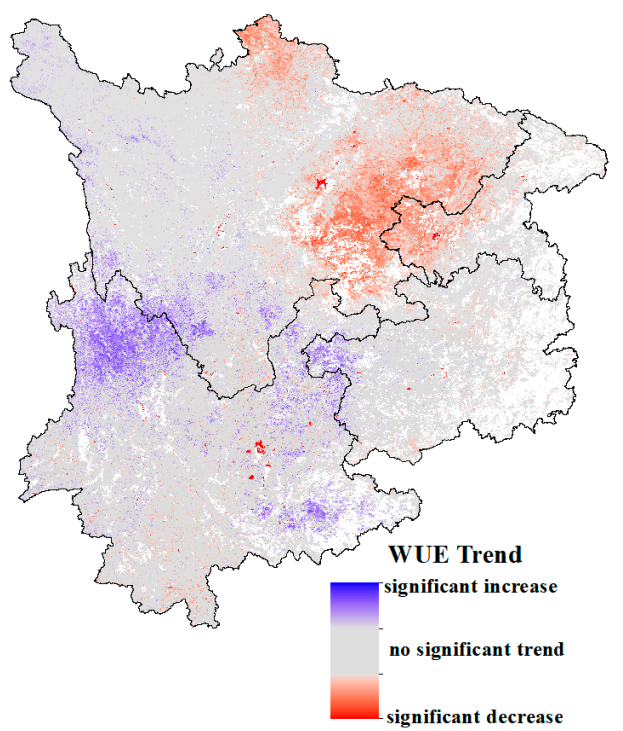

Figure 5. The mean annual WUE and the trend in annual WUE over Southwest China from 2000 to 2017: (a) mean annual WUE; (b) trend of annual WUE.

\subsection{Responses of WUE to Drought in Southwest China}

The spatially averaged mean annual WUE values under different wet or dry conditions are shown in Figure 6. The mean annual WUE averaged over all vegetated grid cells increased as the wet or dry conditions changed from moderate humid to moderate drought. The mean annual WUE of forests and shrublands generally increased with the wet or dry conditions changing from humid to drought, and reached their peak values ( 2.43 and $2.13 \mathrm{gC} \mathrm{kg}^{-1} \mathrm{H}_{2} \mathrm{O}$, respectively) in moderate drought. The grasslands were more sensitive to drought with WUE increased to the peak value $\left(1.2 \mathrm{gC} \mathrm{kg}^{-1} \mathrm{H}_{2} \mathrm{O}\right)$ under slight drought. The WUE of croplands was the highest for the slight humid category and then decreased as the wet or dry conditions changed from slight humid to moderate drought.

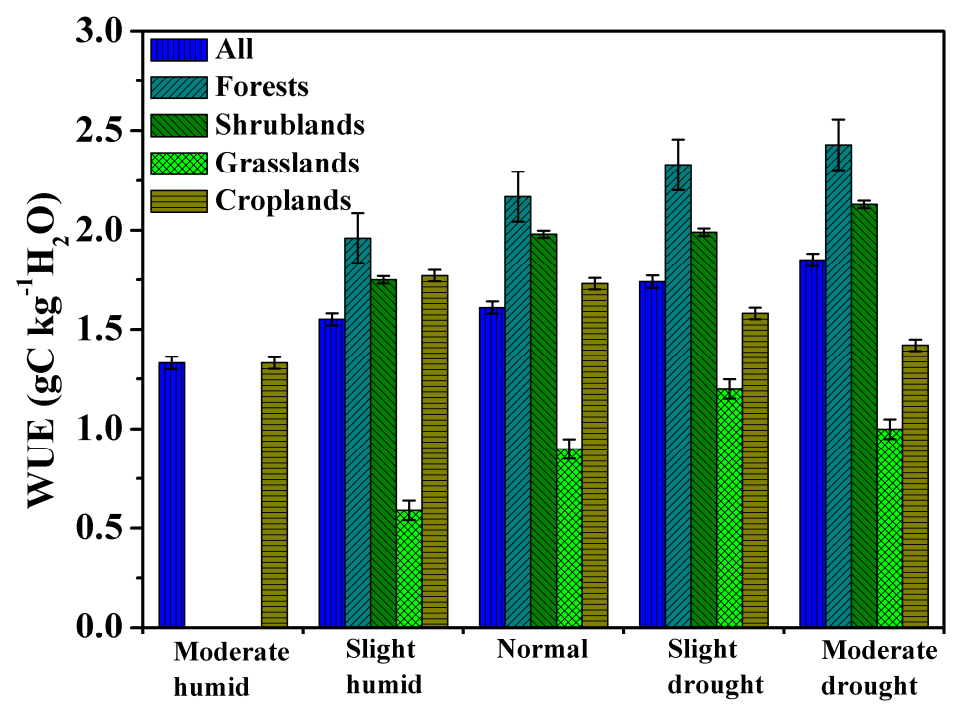

Figure 6. Mean annual WUE spatially averaged for all vegetated grid cells and each of the four broad vegetation types under different wet or dry conditions.

The percentage of drought area (scPDSI $<-1$ ) was used to identify drought years (Figure 2a). We selected two drought years, 2006 and 2010, for further analysis. The average data of the study 
period 2000-2017, excluding the two identified drought years (2006 and 2010), were used as the normal year. The $\triangle W U E$ was used to study the impacts of drought on ecosystem WUE. Although the spatial distributions of WUE in 2006, 2010, and the normal year were generally similar (Figure 7), the WUE anomalies for $2006\left(\Delta W_{2006}\right)$ and $2010\left(\Delta W E_{2010}\right)$ showed positive and negative values (Figure 8). $\Delta W E_{2006}$ and $\Delta W U E_{2010}$ generally had opposite values in the Sichuan Basin, southwestern Yunnan, and Guizhou Province (Figure 8). The effects of drought on WUE were also different for different vegetation types (Table 3). In 2006, WUE increased for 55.3\%, 70.2\%, 79.1\%, and 80.9\% of the grid cells covered by forests, shrublands, grasslands, and croplands, respectively, and increased for more than $70 \%$ of all the vegetated grid cells for the whole region. In 2010, WUE increased for more grid cells for forests and grasslands and decreased for more grid cells for croplands.

(a) Drought year 2006

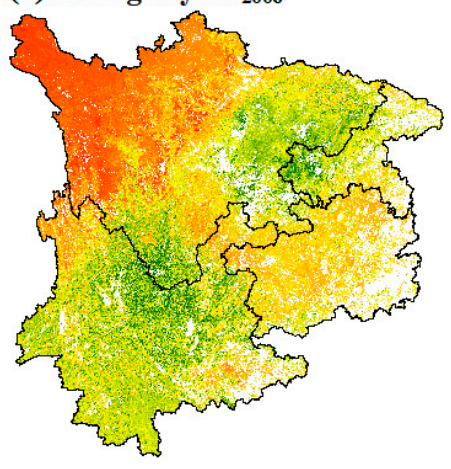

(b) Drought year 2010

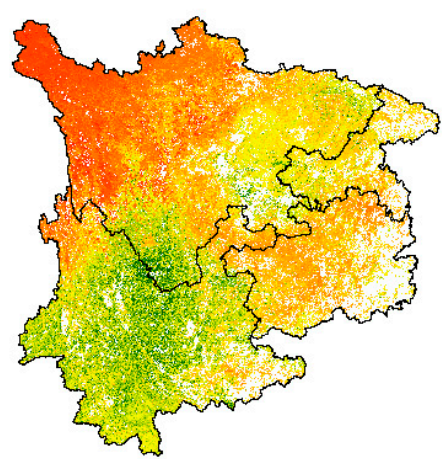

WUE (gC kg-1 $\left.\mathrm{H}_{2} \mathrm{O}\right)$ (c) Normal year

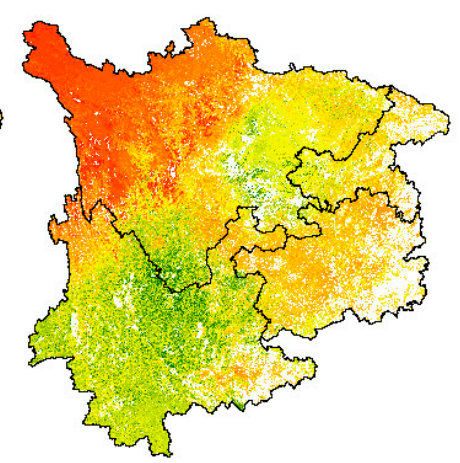

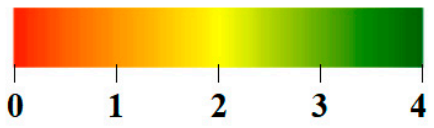

Figure 7. Spatial distribution of annual WUE in (a) 2006 (drought year), (b) 2010 (drought year), and (c) the normal year.

(a) $\triangle \mathrm{WUE} 2006$

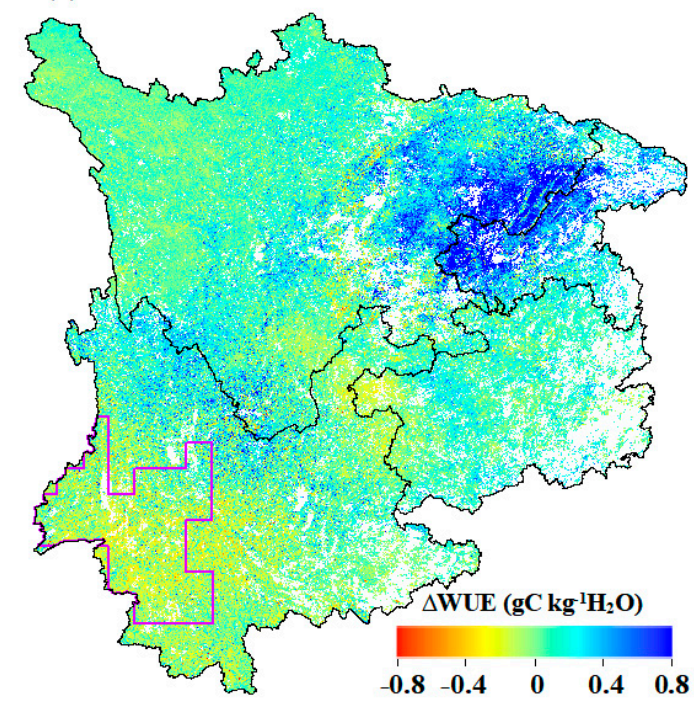

(b) $\triangle \mathrm{WUE} 2010$

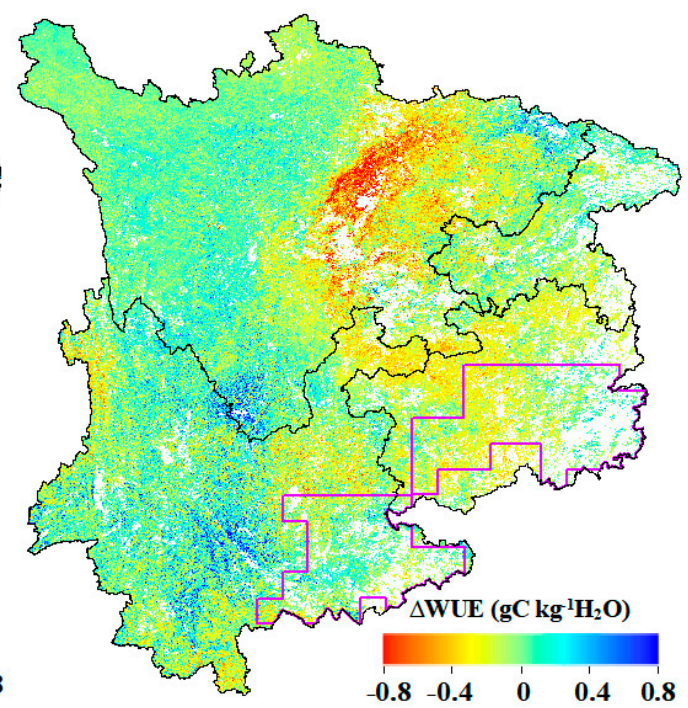

Figure 8. Magnitude and spatial patterns of annual WUE anomalies in Southwest China in 2006 (a) and 2010 (b). Severe drought areas are delineated by the purple polygons. 
Table 3. Percentages of grid cells with $\Delta W U E>0$ and $\Delta W U E<0$ in 2006 and 2010 for different vegetation types and all vegetated areas in Southwest $C$ hina.

\begin{tabular}{crccc}
\hline Vegetation Type & $\boldsymbol{\Delta} \mathbf{W U E}_{\mathbf{2 0 0 6}}<\mathbf{0}$ & $\boldsymbol{\Delta} \mathbf{W} \mathbf{U E}_{\mathbf{2 0 0 6}}>\mathbf{0}$ & $\boldsymbol{\Delta W} \mathbf{W E}_{\mathbf{2 0 1 0}}<\mathbf{0}$ & $\boldsymbol{\Delta} \mathbf{W} \mathbf{U E}_{\mathbf{2 0 1 0}}>\mathbf{0}$ \\
\hline Forests & $44.7 \%$ & $55.3 \%$ & $46.4 \%$ & $53.6 \%$ \\
Shrublands & $29.8 \%$ & $70.2 \%$ & $50.6 \%$ & $49.4 \%$ \\
Grasslands & $20.9 \%$ & $79.1 \%$ & $46.0 \%$ & $54.0 \%$ \\
Croplands & $19.1 \%$ & $80.9 \%$ & $78.8 \%$ & $21.2 \%$ \\
All & $27.7 \%$ & $72.3 \%$ & $56.4 \%$ & $43.6 \%$ \\
\hline
\end{tabular}

The areas with severe drought in 2006 and 2010 (Figure 8) were selected to further analyze the impacts of drought on ecosystem WUE. In 2006, southwestern Yunnan was selected as a typical region of drought occurrence. In this area, the scPDSI was mostly negatively correlated with WUE because the moderate and severe drought $(-4<$ scPDSI $<-2)$ enhanced WUE (Figure 9a,c). In 2010, the WUE in the area highlighted in Figure $8 \mathrm{~b}$ showed a quadratic correlation with scPDSI and a peak value was observed because the extreme drought $(-5<$ scPDSI $<-4)$ reduced WUE (Figure $9 \mathrm{~b}$ ).
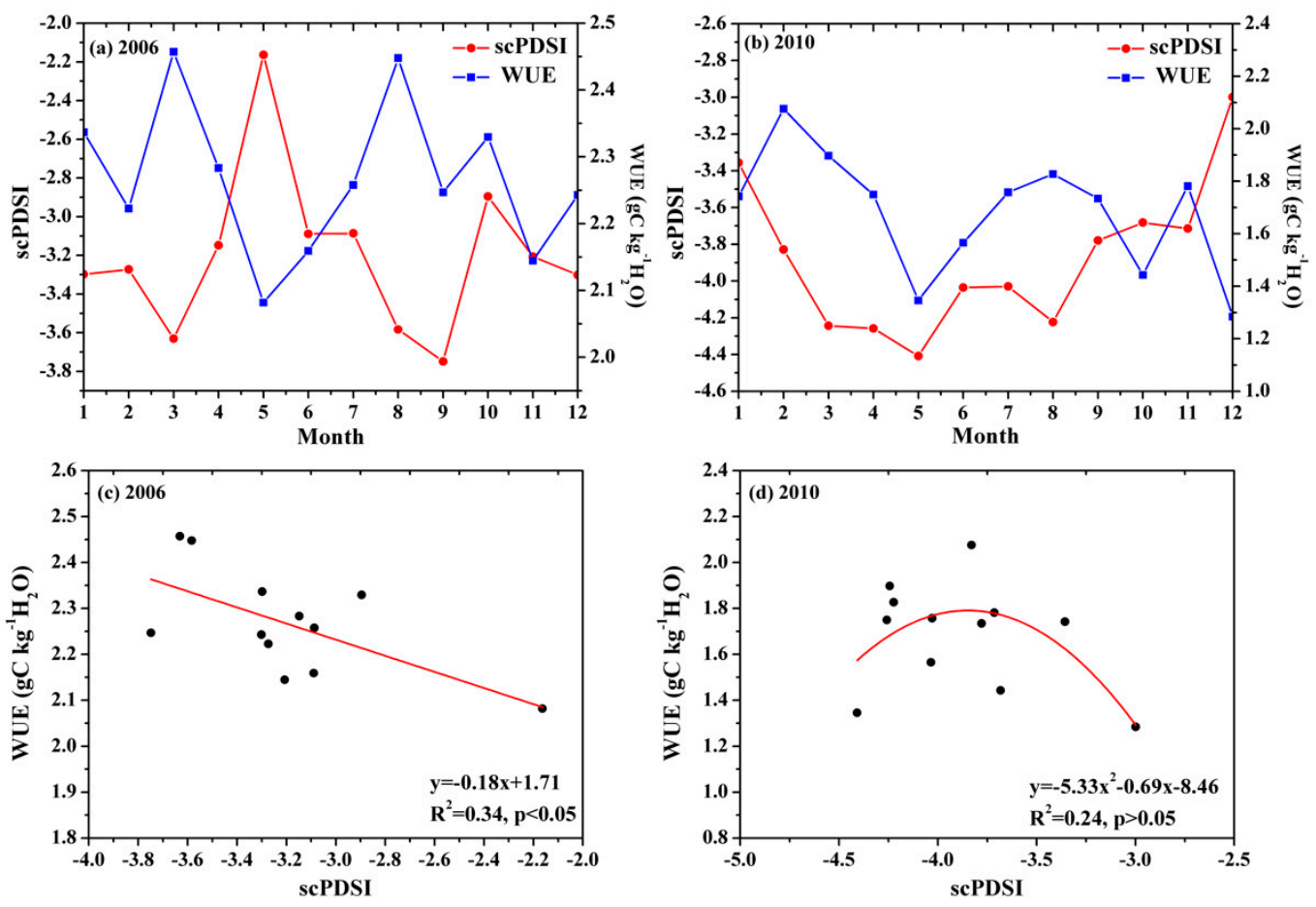

Figure 9. Responses of monthly WUE to drought: (a) seasonal variations of WUE and scPDSI in the selected drought region (Figure 8a) in 2006; (b) seasonal variations of WUE and scPDSI in the selected drought region (Figure 8b) in 2010; (c) the relationship between monthly WUE and monthly scPDSI in 2006; (d) the relationship between monthly WUE and monthly scPDSI in 2010.

We further explored the responses of ecosystem WUE to drought at the monthly timescale for different vegetation types (Figure 10). The monthly WUE of both forests and shrublands increased first and then decreased with the aggravation of drought, and the inflection points of WUE were -3.4 and -3.2 for scPDSI, respectively. However, no inflection points in monthly WUE were found for grasslands and croplands. The monthly WUE of grasslands and croplands linearly and nonlinearly decreased with increasing drought severity, respectively. 

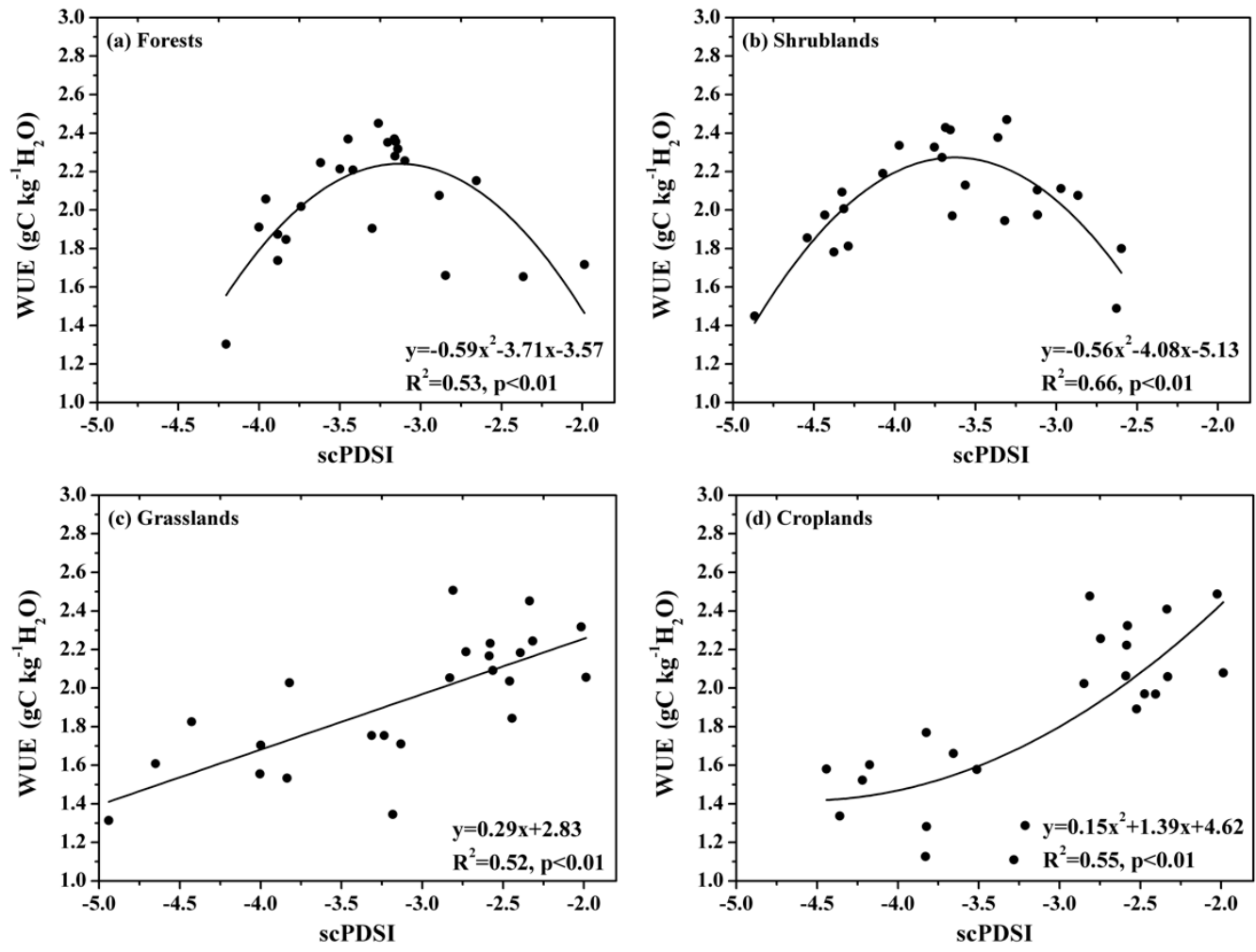

Figure 10. Responses of WUE to drought at the monthly timescale in areas affected by severe drought for different vegetation types: (a) forests; (b) shrublands; (c) grasslands; (d) croplands.

The responses of ecosystem WUE to water status at the monthly timescale may be affected by different plant growth periods. Therefore, we also examined how annual WUE changed with scPDSI (Figure 11). The relationship between WUE and scPDSI at the annual timescale also varied among vegetation types. For forests, shrublands, and croplands, annual WUE showed a pattern of increasing first and then decreasing with the decrease of scPDSI. For grasslands, annual WUE decreased first and then increased with the decrease of scPDSI. In addition, forests showed relatively strong adaptability to drought as annual WUE was relatively stable under moderate drought; the WUE of shrublands was sensitive to drought, and it reached the peak value when scPDSI was near 0; the WUE of grasslands and croplands were also sensitive to wet or dry conditions; and the valley/peak value of WUE was reached when scPDSI was -0.5 to 0 .

The patterns of annual WUE with changing scPDSI depended on the responses of annual GPP and ET to scPDSI (Figure 11). GPP and ET had different patterns with the changes in scPDSI. For example, with the decrease of scPDSI, GPP showed the pattern of first increasing and then decreasing, while ET continued to slowly decrease. For all the four broad vegetation types, the variations of annual GPP with scPDSI were generally similar to those of annual WUE. Therefore, the variations in annual WUE with changing wet or dry conditions were mainly caused by the variations in annual GPP. 

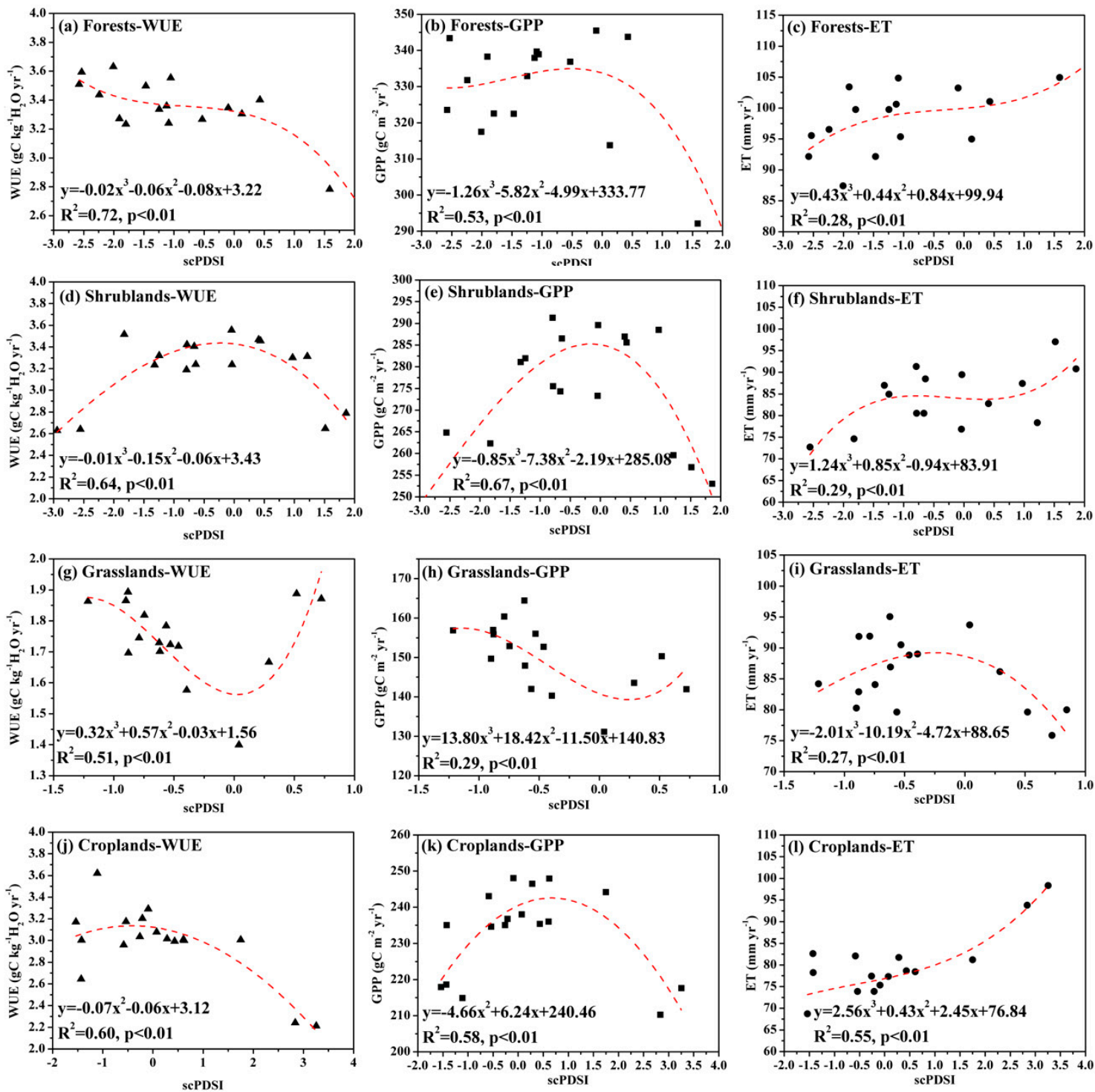

Figure 11. Variations of annual WUE, GPP, and ET with changing wet or dry conditions (scPDSI) over the period 2000-2017 for forests $(\mathbf{a}-\mathbf{c})$, shrublands $(\mathbf{d}-\mathbf{f})$, grasslands $(\mathbf{g}-\mathbf{i})$, and croplands $(\mathbf{j}-\mathbf{l})$.

\section{Discussion}

Many studies have examined the effects of drought on WUE. Some researchers believed that drought could lead to a significant increase in the WUE of natural ecosystems [24,50] while others suggested that drought could reduce the WUE of most ecosystems [51,52]. The responses of water and the carbon cycle to drought in the terrestrial ecosystem are affected by many biological and abiotic factors. Previous studies have pointed out that the WUE had a significant intrinsic variability and plasticity, which may be caused by inheritance [53]. For example, $\mathrm{C}_{4}$ plants generally have a stronger water use ability than $C_{3}$ plants [54]. The long-term living environment will affect the adaptability of plants to drought. Some plants living in arid regions have a high drought tolerance gene [55], which can improve their resistance to drought stress; some plants (e.g., cactus) increase their resistance to drought stress through metamorphic leaves [56]. In wet areas, high temperature and high evaporation can lead to the decline of WUE while for plants in alpine areas, the WUE is often relatively low because of the high wind speed and solar radiation [50].

Our study shows that overall, drought slightly increased the WUE of most forest, grassland, and shrubland ecosystems while there were turning points when drought became more severe. The increase in the WUE suggests that under certain water stress, plants can achieve higher productivity with 
the same amount of water lost to ET or the same productivity with lower ET; when the degree of water stress exceeds the ability of plant self-regulation, however, drought will reduce the normal physiological metabolism level of plants [57]. Moreover, drought has different inhibition points on WUE for different vegetation types. On the whole, croplands had the lowest resistance to drought, which is also related to the vulnerability and higher productivity of these ecosystems. Therefore, croplands could require higher stability of water availability, and mild drought can cause fluctuations of WUE. The WUE of grasslands was also sensitive to drought, and moderate drought ( $\operatorname{scPDSI}=-3$ to -2) could reduce ecosystem WUE. This is consistent with previous research results [58], which found that grasslands can maintain the normal water metabolic demand through root extension under mild drought, and improve WUE by controlling transpiration. The grass root system is relatively shallow, and its drought mediation ability is limited, and more serious water deficit could lead to the decline of grasslands productivity and WUE. The forests and shrublands in Southwest China are dominated by perennial deciduous and evergreen forests that have deeper roots and stronger ability to utilize groundwater; therefore, short-term drought or mild drought could enhance the WUE of forests and shrublands while more severe or long-term drought could decrease WUE.

The responses of WUE to drought varied with region, season, and vegetation type. The drought areas in 2010 were characterized by mixed areas of croplands, grasslands, and forests, but the proportion of croplands was relatively large. With the increase of drought intensity, WUE exhibited a significant quadratic curve pattern (Figure 9b), which is different from the overall analysis results that drought led to the decline of WUE in croplands (Figures 6 and 10d). However, WUE and scPDSI showed a negative correlation (WUE decreased due to drought) from January to June (early and middle growth period) and positive correlation (drought enhanced WUE) during July to August (mature period). In the early stage of crop growth (e.g., the jointing stage of corn, the heading stage of rice, the flourishing and long term of flue-cured tobacco), the cropland growth is faster and is sensitive to water demand, and therefore the water deficit leads to a serious decline in productivity and WUE. During July to August (the maturity stage of crops), the plants mainly accumulate dry materials through photosynthesis; as the roots of crops are well developed, the absorption capacity of roots to soil effective water is the strongest, and the high ground canopy coverage can also effectively inhibit soil evaporation; thus, the ecosystem WUE of croplands is relatively high. GPP and ET are two components that directly influence the change of ecosystem WUE [59-61]. The different sensitivity of ecosystem GPP and ET to drought results in different responses of WUE to drought. It has been reported that the ecosystem WUE increased under drought stress because the decrease of GPP was less than that of ET [62]. Contrary to some previous studies [63], our results showed that the relationships between WUE and drought varied with vegetation type in Southwest China, indicating the different sensitivity of different vegetation types to drought.

The responses of WUE to water deficit during drought has been reported in previous studies, but few studies have been conducted on the changes of WUE after the end of persistent drought events $[64,65]$. Studying the responses of WUE following drought can help us understand the ability of different ecosystems to recover after drought and to cope with another drought [66]. Vegetation has lagged responses to environmental factors, such as rainfall and temperature, and ecosystem WUE also has lagged responses to drought [8]. During the drought stress period, the drought in the previous year and current year both affected the WUE of terrestrial ecosystems (forests, shrublands, grasslands, and croplands). The regionally averaged WUE had a stronger correlation with drought in the previous year than with drought in the current year (Table 4). This indicates that the drought in the previous year could have larger effects on ecosystem WUE than drought stress in the current year. After drought stress, WUE in the current year was more closely related to the current-year drought than to the previous-year drought. Therefore, the lag effect of drought was not obvious under normal water conditions $[67,68]$. 
Table 4. Analysis of the lag effect of drought on WUE.

\begin{tabular}{ccccc}
\hline TIME & WUE $_{\mathbf{2 0 0 7}}-$ scPDSI $_{\mathbf{2 0 0 6}}$ & WUE $_{\mathbf{2 0 0 7}}-$ scPDSI $_{\mathbf{2 0 0 7}}$ & WUE $_{\mathbf{2 0 1 1}}$-scPDSI $_{\mathbf{2 0 1 0}}$ & WUE $_{\mathbf{2 0 1 1}}$-scPDSI $_{\mathbf{2 0 1 1}}$ \\
\hline $\mathrm{R}^{2}$ & 0.45 & 0.37 & 0.44 & 0.36 \\
\hline
\end{tabular}

The differences of ecosystem WUE under different drought conditions found in this study were consistent with previous results [69]. The spatial differences of WUE were mainly determined by the environmental factors and the heterogeneity of physiological characteristics among plant species [6]. In addition, the drought resistance of ecosystems depends on various factors, such as drought severity, drought duration, drought extent, vegetation type, plant growth rate, and inter-species competition, and scale differences in drought observation. The stability of ecosystems is related to not only the resistance of plants to water stress but also the recovery of plants (i.e., resilience) [70]. Our results showed that croplands had a weak resistance to drought. Usually, croplands under a water deficit would reduce photosynthesis and aboveground biomass and increase underground biomass, and this is also a survival strategy of ecosystems in arid and semi-arid areas. After severe drought, an ecosystem needs a recovery period [71]. If another drought occurs, the recovered ecosystem can respond quickly and to some extent ensure the stability of the ecosystem WUE level [9]. The resilience of ecosystem WUE found in this study is consistent with previous studies [26,69]. To some extent, ecosystems can adapt to changing hydro-climatic conditions by adjusting its WUE, and after drought, ecosystems can restore their pre-drought status through self-regulation with improved soil water availability [72].

\section{Conclusions}

We analyzed the temporal and spatial patterns of WUE and its responses to drought in Southwest China using the MODIS data products (GPP and ET) and the scPDSI drought index. From 2000 to 2017, the mean annual WUE differed among broad vegetation types, with forests having the largest WUE ( $\left.3.25 \mathrm{gC} \mathrm{kg}^{-1} \mathrm{H}_{2} \mathrm{O}\right)$, followed by shrublands (2.00 $\left.\mathrm{gC} \mathrm{kg}^{-1} \mathrm{H}_{2} \mathrm{O}\right)$, croplands $\left(1.76 \mathrm{gC} \mathrm{kg}^{-1} \mathrm{H}_{2} \mathrm{O}\right)$, and grasslands $\left(1.04 \mathrm{gC} \mathrm{kg}^{-1} \mathrm{H}_{2} \mathrm{O}\right)$. Annual WUE was higher in the Sichuan basin and Yunnan and lower in Guizhou and western Sichuan Plateau. Annual WUE showed a gradual downward trend from 2000 to 2017. The WUE was sensitive to drought, and overall, drought had an enhancement effect on WUE. However, the responses of WUE to drought varied with vegetation type and drought severity. WUE was the most sensitive to drought over croplands, and a slight water deficit was likely to reduce cropland WUE. The drought resistance of grasslands was relatively weak because of its shallow root system; mild drought could increase its WUE while moderate and severe drought could reduce its WUE. The adaptability of forests and shrublands to drought was relatively strong; moderate drought could increase their WUE, and only severe drought could reduce their WUE. Our findings can help us better understand plant water use strategy and inform ecosystem water management.

Author Contributions: Conceptualization, T.X.; methodology, J.X.; software, H.F.; validation, X.H.; formal analysis, K.M.; investigation, L.S.; resources, S.L.; data curation, Y.Y.; writing-original draft preparation, J.Z.; writing-review and editing, J.X. and T.X.; supervision, T.X.; project administration, S.L.; funding acquisition, T.X. All authors have read and agreed to the published version of the manuscript.

Funding: This work is supported by the Strategic Priority Research Program of the Chinese Academy of Sciences (Grant no. XDA20100101), National Natural Science Foundation of China $(41671335,91647104)$ and project supported by State Key Laboratory of Earth Surface Processes and Resource Ecology (2017-KF-16).

Acknowledgments: Annual GPP and ET data with 1-km resolution were both obtained from MODIS products (http://www.ntsg.umt.edu). The scPDSI data product is available from the University of East Anglia (UEA) (http://www.cru.uea.ac.uk/).

Conflicts of Interest: The authors declare no conflict of interest.

\section{References}

1. Ito, A.; Inatomi, M. Water-use efficiency of the terrestrial biosphere: A model analysis focusing on interactions between the global carbon and water cycles. J. Hydrometeorol. 2012, 13, 681-694. [CrossRef] 
2. Aguilos, M.; Stahl, C.; Burban, B.; Herault, B.; Courtois, E.A.; Coste, S.; Wagner, F.; Ziegler, C.; Takagi, K.; Bonal, D. Interannual and seasonal variations in ecosystem transpiration and water use efficiency in a tropical rainforest. Forests 2019, 10, 14. [CrossRef]

3. Jiang, L.; Yang, Y.T.; Shang, S.H. Evaluation on irrigation efficiency of irrigation district in arid region based on evapotranspiration estimated from remote sensing data. Trans. Chin. Soc. Agric. Eng. 2013, 29, 95-101.

4. Keenan, T.F.; Hollinger, D.Y.; Bohrer, G.; Dragoni, D.; Munger, J.W.; Schmid, H.P.; Richardson, A.D. Increase in forest water-use efficiency as atmospheric carbon dioxide concentrations rise. Nature 2013, 499, 324-327. [CrossRef] [PubMed]

5. Guerrieri, R.; Belmecheri, S.; Ollinger, S.V.; Asbjornsen, H.; Jennings, K.A.; Xiao, J.F.; Stocker, B.D.; Martin, M.E.; Hollinger, D.Y.; Brachogarrillo, R.; et al. Disentangling the role of photosynthesis and stomatal conductance on rising forest water-use efficiency. Proc. Natl. Acad. Sci. USA 2019, 116, 16909-16914. [CrossRef] [PubMed]

6. Zhu, X.J.; Yu, G.R.; Wang, Q.F.; Hu, Z.M.; Zheng, H.; Li, S.G.; Sun, X.M.; Zhang, Y.P.; Yan, J.H.; Wang, H.M.; et al. Spatial variability of water use efficiency in China's terrestrial ecosystems. Glob. Planet. Chang. 2015, 129, 37-44. [CrossRef]

7. Wang, M.J.; Chen, Y.H.; Wu, X.C.; Bai, Y. Forest-type-dependent water use efficiency trends across the northern hemisphere. Geophys. Res. Lett. 2018, 45, 8283-8293. [CrossRef]

8. Liu, Y.B.; Xiao, J.F.; Ju, W.M.; Zhou, Y.L.; Wang, S.Q.; Wu, X.C. Water use efficiency of China's terrestrial ecosystems and responses to drought. Sci. Rep. 2015, 5, 13799. [CrossRef]

9. Guo, L.M.; Sun, F.B.; Liu, W.B.; Zhang, Y.G.; Wang, H.; Cui, H.J.; Wang, H.Q.; Zhang, J.; Du, B.X. Response of ecosystem water use efficiency to drought over China during 1982-2015: Spatiotemporal variability and resilience. Forests 2019, 10, 598. [CrossRef]

10. Yang, Y.T.; Guan, H.D.; Batelaan, O.; Mcvicar, T.R.; Long, D.; Piao, S.L.; Liang, W.; Liu, B.; Jin, Z.; Simmons, C.T. Contrasting responses of water use efficiency to drought across global terrestrial ecosystems. Sci. Rep. 2016, 6, 23284. [CrossRef]

11. Schwalm, C.R.; Anderegg, W.R.L.; Michalak, A.M.; Fisher, J.B.; Biondi, F.; Koch, G.W.; Litvak, M.E.; Ogle, K.; Shaw, G.D.; Wolf, A.; et al. Global patterns of drought recovery. Nature 2017, 7666, 202-205. [CrossRef] [PubMed]

12. Trenberth, K.E.; Dai, A.; Gerard, V.D.S.; Jones, P.D.; Barichivich, J.; Briffa, K.R.; Sheffield, J. Global warming and changes in drought. Nat. Clim. Chang. 2013, 4, 17-22. [CrossRef]

13. Mohammad, A.H.; Jung, H.C.; Odeh, T.; Bhuiyan, C.; Hussein, H. Understanding the impact of droughts in the Yarmouk Basin, Jordan: Monitoring droughts through meteorological and hydrological drought indices. Arab. J. Geosci. 2018, 11, 103. [CrossRef]

14. Zhang, L.; Xiao, J.F.; Zhou, Y.; Zheng, Y.; Li, J.; Xiao, H. Drought events and their effects on vegetation productivity in China. Ecosphere 2016, 7, 01591. [CrossRef]

15. Diffenbaugh, N.S.; Swain, D.L.; Touma, D. Anthropogenic warming has increased drought risk in california. Proc. Natl. Acad. Sci. USA 2015, 112, 3931-3936. [CrossRef]

16. Ciais, P.; Reichstein, M.; Viovy, N.; Granier, A.; Ogee, J.; Allard, V.; Aubinet, M.; Buchmann, N.; Bernhofer, C.; Carrara, A.; et al. Europe-wide reduction in primary productivity caused by the heat and drought in 2003. Nature 2005, 437, 529-533. [CrossRef]

17. Klumpp, K.; Soussana, J.F.; Falcimagne, R. Effects of past and current disturbance on carbon cycling in grassland mesocosms. Agric. Ecosyst. Environ. 2007, 121, 59-73. [CrossRef]

18. Ahmadi, B.; Moradkhani, H. Revisiting hydrological drought propagation and recovery considering water quantity and quality. Hydrol. Process. 2019, 33, 1492-1505. [CrossRef]

19. Downingm, C.G. The evaporation of drops of pure liquids at elevated temperatures: Rates of evaporation and wet-bulb temperatures. AIChE J. 2010, 12, 760-766. [CrossRef]

20. Xie, Z.H.; Wang, L.Y.; Jia, B.H.; Yuan, X. Measuring and modeling the impact of a severe drought on terrestrial ecosystem $\mathrm{CO}_{2}$ and water fluxes in a subtropical forest. J. Geophys. Res. 2016, 121, 2576-2587. [CrossRef]

21. Wu, X.C.; Li, X.Y.; Chen, Y.H.; Bai, Y.; Tong, Y.Q.; Wang, P.; Liu, H.Y.; Wang, M.J.; Shi, F.Z.; Zhang, C.C.; et al. Atmospheric water demand dominates daily variations in water use efficiency in alpine meadows, northeastern Tibetan Plateau. J. Geophys. Res. Biogeosci. 2019, 124, 2174-2185. [CrossRef]

22. Wang, W.; Wang, W.J.; Li, J.S.; Wu, H.; Xu, C.; Liu, T. The impact of sustained drought on vegetation ecosystem in Southwest China based on remote sensing. Procedia Environ. Sci. 2010, 2, 1679-1691. [CrossRef] 
23. Salehyan, I. Climate change and conflict: Making sense of disparate findings. Polit. Geogr. 2014, 43, 1-5. [CrossRef]

24. Buhaug, H.; Nordkvelle, J.; Bernauer, T.; Bohmelt, T.; Brzoska, M.; Busby, J.W.; Ciccone, A.; Fjelde, H.; Gartzke, E.; Gleditsch, N.P.; et al. One effect to rule them all? A comment on climate and conflict. Clim. Chang. 2014, 127, 391-397. [CrossRef]

25. Zhao, F.; Wang, R. Discrimination of drought occurrence for rainfed spring wheat in semi-arid area based on pattern recognition. Trans. Chin. Soc. Agric. Eng. 2014, 30, 124-132.

26. Huang, L.; He, B.; Han, L.; Liu, J.J.; Wang, H.Y.; Chen, Z.Y. A global examination of the response of ecosystem water-use efficiency to drought based on MODIS data. Sci. Total Environ. 2017, 601, 1097-1107. [CrossRef]

27. Li, X.Y.; Li, Y.; Chen, A.P.; Gao, M.D.; Slette, I.J.; Piao, S.L. The impact of the 2009/2010 drought on vegetation growth and terrestrial carbon balance in Southwest China. Agric. For. Meteorol. 2019, 269, 239-248. [CrossRef]

28. Ngugi, M.R.; Hunt, M.A.; David, D.; Ryan, P.; Dart, P.J. Effects of soil water availability on water use efficiency of Eucalyptus cloeziana and Eucalyptus argophloia plants. Aust. J. Bot. 2003, 51, 159-166. [CrossRef]

29. Niu, S.L.; Peng, Y.; Jiang, G.M.; Li, Y.G.; Gao, L.M.; Liu, M.Z.; Cui, H.X.; Ding, L. Differential responses to simulated precipitation exhibited by a typical shrub and a herb coexisted in hunshandak sandy land. Acta Bot. Sin. 2004, 46, 1170-1177.

30. Wells, N.; Goddard, S.; Hayes, M.J. A self-calibrating palmer drought severity index. J. Clim. 2004, 17, 2335-2351. [CrossRef]

31. Running, S.W.; Nemani, R.R.; Heinsch, F.A.; Zhao, M.S.; Reeves, M.C.; Hashimoto, H. A continuous satellite-derived measure of global terrestrial primary production. BioScience 2004, 54, 547-560. [CrossRef]

32. Zhao, M.S.; Heinsch, F.A.; Nemani, R.R.; Running, S.W. Improvements of the MODIS terrestrial gross and net primary production global data set. Remote Sens. Environ. 2005, 95, 164-176. [CrossRef]

33. Mu, Q.Z.; Heinsch, F.A.; Zhao, M.S.; Running, S.W. Development of a global evapotranspiration algorithm based on MODIS and global meteorology data. Remote Sens. Environ. 2007, 111, 519-536. [CrossRef]

34. Mu, Q.Z.; Zhao, M.S.; Running, S.W. Improvements to a MODIS global terrestrial evapotranspiration algorithm. Remote Sens. Environ. 2011, 115, 1781-1800. [CrossRef]

35. Tao, J.B.; Mishra, D.; Cotten, D.L.; Oconnell, J.J.; Leclerc, M.Y.; Nahrawi, H.; Zhang, G.S.; Pahari, R. A comparison between the MODIS product (MOD17A2) and a tide-robust empirical GPP model evaluated in a georgia wetland. Remote Sens. 2018, 10, 1831. [CrossRef]

36. Turner, D.P.; Ritts, W.D.; Cohen, W.B.; Gower, S.T.; Running, S.; Zhao, M.S.; Costa, M.H.; Kirschbaum, A.A.; Ham, J.M.; Saleska, S.R.; et al. Evaluation of MODIS NPP and GPP products across multiple biomes. Remote Sens. Environ. 2006, 102, 282-292. [CrossRef]

37. Xue, B.L.; Guo, Q.H.; Otto, A.; Xiao, J.F.; Tao, S.L.; Li, L. Global patterns, trends, and drivers of water use efficiency from 2000 to 2013. Ecosphere 2015, 6, 1-18. [CrossRef]

38. Zscheischler, J.; Mahecha, M.D.; Von, B.T.; Harmeling, S.; Jung, M.; Rammig, A.; Randerson, T.J.; Scholkopf, B.; Seneviratne, I.S.; Tomelleri, E.; et al. A few extreme events dominate global interannual variability in gross primary production. Environ. Res. Lett. 2014, 9, 036001. [CrossRef]

39. Wolf, S.; Keenan, T.F.; Fisher, J.B.; Baldocchi, D.D.; Desai, A.R.; Richardson, A.D.; Scott, R.S.; Law, B.E.; Litvak, M.E.; Brunsell, N.A.; et al. Warm spring reduced carbon cycle impact of the 2012 US summer drought. Proc. Natl. Acad. Sci. USA 2016, 113, 5880-5885. [CrossRef]

40. Mu, Q.; Zhao, M.; Running, S.W. MODIS Global Terrestrial Evapotranspiration (ET) Product (NASA MOD16A2/A3); Algorithm Theoretical Basis Document, Collection. 5; Numerical Terradynamic Simulation Group, University of Montana: Missoula, MT, USA, 2013.

41. Velpuri, N.M.; Senay, G.B.; Singh, R.K.; Bohms, S.; Verdin, J.P. A comprehensive evaluation of two MODIS evapotranspiration products over the conterminous United States: Using point and gridded FLUXNET and water balance ET. Remote Sens. Environ. 2013, 139, 35-49. [CrossRef]

42. Kim,H.W.; Hwang, K.; Mu, Q.; Lee, S.O.; Choi, M. Validation of MODIS 16 global terrestrial evapotranspiration products in various climates and land cover types in Asia. KSCE J. Civ. Eng. 2012, 16, 229-238. [CrossRef]

43. Palmer, W.C. Meteorological Drought; U.S. Department of Commerce Weather Bureau Research Paper; U.S. Government Printing Office: Washington, DC, USA, 1965; Volume 45, p. 58.

44. Wang, Z.; Li, J.; Huang, Z. Spatiotemporal variations analysis of meteorological drought in China based on scPDSI. Trans. Chin. Soc. Agric. Eng. 2016, 32, 161-168. 
45. Sun, H.Y.; Liu, C.M.; Zhang, X.Y.; Shen, Y.J.; Zhang, Y.Q. Effects of irrigation on water balance, yield and WUE of winter wheat in the North China Plain. Agric. Water Manag. 2006, 85, 211-218. [CrossRef]

46. Kendall, M.G. A new measure of rank correlation. Biometrika 1938, 30, 81-93. [CrossRef]

47. Mann, H.B. Nonparametric tests against trend. Econometrica 1945, 13, 245-259. [CrossRef]

48. Yue, S.; Pilon, P.; Cavadias, G. Power of the ann-Kendall and Spearman's rho tests for detecting monotonic trends in hydrological series. J. Hydrol. 2002, 259, 254-271. [CrossRef]

49. Hamed, K.H.; Rao, A.R. A modified Mann-Kendall trend test for autocorrelated data. J. Hydrol. 1998, 204, 182-196. [CrossRef]

50. Ponce Campos, G.E.; Moran, M.S.; Huete, A.; Zhang, Y.G.; Bresloff, C.J.; Huxman, T.E.; Eamus, D.; Bosch, D.D.; Buda, A.R.; Gunter, S.A.; et al. Ecosystem resilience despite large-scale altered hydroclimatic conditions. Nature 2013, 494, 349-352. [CrossRef]

51. Samanta, A.; Ganguly, S.; Hashimoto, H.; Devadiga, S.; Vermote, E.F.; Knyazikhin, Y.; Nemani, R.R.; Myneni, R.B. Amazon forests did not green-up during the 2005 drought. Geophys. Res. Lett. 2010, 37, 05401. [CrossRef]

52. Gang, C.C.; Wang, Z.Q.; Chen, Y.Z.; Yang, Y.; Li, J.L.; Cheng, J.M.; Qi, J.Q.; Odeh, I.O.A. Drought-induced dynamics of carbon and water use efficiency of global grasslands from 2000 to 2011. Ecol. Indic. 2016, 67, 788-797. [CrossRef]

53. Zhang, Z.B.; Shan, L.; Xu, Q. Background analysis of chromosome controling genetic of water use efficiency of Triticum. Acta Cen. Sin. 2000, 27, 240-246.

54. Zhang, X. The study of stable carbon isotope composition in desert plants of Junggar Basin. J. Desert Res. 2007, 27, 972-976.

55. Feng, M.S. Impact of the continuous drought on the depth of dry soil layer and on the existence of plants. Arid Zone Res. 2002, 19, 71-74.

56. Hernandezsantana, V.; Rodriguezdominguez, C.M.; Fernandez, J.E.; Diazespejo, A. Role of leaf hydraulic conductance in the regulation of stomatal conductance in almond and olive in response to water stress. Tree Physiol. 2016, 36, 725-735. [CrossRef]

57. Huang, X.T.; Luo, G.P. Spatio-temporal characteristics of evapotranspiration and water use efficiency in grasslands of Xinjiang. J. Plant. Ecol. 2017, 41, 506-518.

58. Kuglitsch, F.G.; Reichstein, M.; Beer, C.; Carrara, A.; Ceulemans, R.; Granier, A.; Janssens, I.A.; Koestner, B.; Lindroth, A.; Loustau, D.; et al. Characterisation of ecosystem water-use efficiency of European forests from eddy-covariance measurements. BGD 2008, 5, 4481-4519. [CrossRef]

59. Xu, T.R.; He, X.L.; Bateni, S.M.; Auligne, T.; Liu, S.M.; Xu, Z.W.; Zhou, J.; Mao, K.B. Mapping regional turbulent heat fluxes via variational assimilation of land surface temperature data from polar orbiting satellites. Remote Sens. Environ. 2019, 221, 444-461. [CrossRef]

60. Xu, T.R.; Guo, Z.X.; Liu, S.M.; He, X.L.; Meng, Y.F.Y.; Xu, Z.W.; Xia, Y.L.; Xiao, J.F.; Zhang, Y.; Ma, Y.F.; et al. Evaluating different machine learning methods for upscaling evapotranspiration from flux towers to the regional scale. J. Geophys. Res. Atmos. 2018, 123, 8674-8690. [CrossRef]

61. Xu, T.R.; Guo, Z.X.; Xia, Y.L.; Ferreira, V.G.; Liu, S.M.; Wang, K.; Yao, Y.J.; Zhang, X.J.; Zhao, C.S. Evaluation of twelve evapotranspiration products from machine learning, remote sensing and land surface models over conterminous United States. J. Hydrol. 2019, 578, 124105. [CrossRef]

62. Qi, X.H.; Zhu, Y.; Zhou, Y.P. Effects of drought on ecosystem carbon and water processes: A review at different scales. Prog. Geogr. 2010, 25, 12-20.

63. Zhang, L.; Xiao, J.F.; Li, J.; Wang, K.; Lei, L.P.; Guo, H.D. The 2010 spring drought reduced primary productivity in southwestern China. Environ. Res. Lett. 2012, 7, 045706. [CrossRef]

64. Chaves, M.M.; Maroco, J.; Pereira, J.S. Understanding plant responses to drought-From genes to the whole plant. Funct. Plant Biol. 2003, 30, 239-264. [CrossRef]

65. Niu, S.L.; Wu, M.Y.; Han, Y.; Xia, J.Y.; Li, L.H.; Wan, S.Q. Water-mediated responses of ecosystem carbon fluxes to climatic change in a temperate steppe. New Phytol. 2008, 177, 209-219. [CrossRef] [PubMed]

66. Ahmadi, B.; Ahmadalipour, A.; Tootle, G.A.; Moradkhani, H. Remote sensing of water use efficiency and terrestrial drought rcovery across the contiguous United States. Remote Sens. 2019, 11, 731. [CrossRef]

67. Heumann, B.W.; Seaquist, J.W.; Eklundh, L.; Jonsson, P. AVHRR derived phenological change in the Sahel and Soudan, Africa, 1982-2005. Remote Sens. Environ. 2007, 108, 85-392. [CrossRef] 
68. Huang, M.T.; Piao, S.L.; Sun, Y.; Ciais, P.; Cheng, L.; Mao, J.F.; Poulter, B.; Shi, X.Y.; Zeng, Z.Z.; Wang, T.P. Change in terrestrial ecosystem water-use efficiency over the last three decades. Glob. Chang. Biol. 2015, 21, 2366-2378. [CrossRef] [PubMed]

69. Zou, J.; Ding, J.; Qin, Y. Response of water use efficiency of Central Asia ecosystem to drought based on remote sensing data. Trans. Chin. Soc. Agric. Eng. 2018, 34, 145-152.

70. Galiano, L.; Martínez-Vilalta, J.; Lloret, F. Drought-induced multifactor decline of scots pine in the pyrenees and potential vegetation change by the expansion of co-occurring oak species. Ecosystems 2010, 13, 978-991. [CrossRef]

71. White, A.B.; Springer, E.P.; Vivoni, E.R. The transformation of a semiarid ecosystem due to severe drought and how it has influenced the hydrologic cycle across varying scales. In Proceedings of the American Geophysical Union Fall Meeting, San Francisco, CA, USA, 15-19 December 2008.

72. Yang, Y.T.; Donohue, R.J.; Mcvicar, T.R.; Roderick, M.L. An analytical model for relating global terrestrial carbon assimilation with climate and surface conditions using a rate limitation framework. Geophys. Res. Lett. 2015, 42, 9825-9835. [CrossRef]

(C) 2020 by the authors. Licensee MDPI, Basel, Switzerland. This article is an open access article distributed under the terms and conditions of the Creative Commons Attribution (CC BY) license (http://creativecommons.org/licenses/by/4.0/). 